\title{
Hubungan ASI Eksklusif dan Riwayat ISPA Terhadap Kolonisasi Streptococcus Pneumoniae pada SWAB Nasofaring Anak Bawah Dua Tahun
}

\author{
Indri Permata Rani', Finny Fitry Yani \\ 1 Fakultas Kedokteran Universitas Andalas Padang, Indonesia \\ ${ }^{2}$ Bagian IImu Kesehatan Anak Fakultas Kedokteran Universitas Andalas/RSUP Dr. M. Djamil Padang, Indonesia
}

\begin{abstract}
A B S T R A C T
Latar Belakang. Pneumonia merupakan penyebab kematian utama pada anak di dunia. Streptococcus Pneumoniae ( $S$. Pneumoniae) sebagai bakteri terbanyak penyebab pneumonia dapat membentuk kolonisasi di nasofaring anak. Faktor yang mempengaruhi kolonisasi S. Pneumoniae ini diantaranya adalah pemberian air susu ibu (ASI) ekslusif dan infeksi saluran pernafasan akut (ISPA) pada anak.

Objektif. Penelitian ini bertujuan untuk mengetahui hubungan pemberian ASI ekslusif dan riwayat ISPA terhadap kolonisasi $S$. Pneumoniae pada swab nasofaring anak usia bawah dua tahun. Metode. Penelitian ini merupakan studi analitik dengan metode cross sectional pada 30 orang anak usia bawah dua tahun. Data mengenai pemberian ASI eksklusif dan riwayat

Data were analyzed by chi square test. The results showed that $63,3 \%$ among children under two years old had $S$. pneumoniae colonization in nasopharynx. Chi square analytical.

Result. Result showed that $p$ value of correlation between exclusive breastfeeding and S. pneumoniae colonization were 0,637 and $p$ value of correlation between respiratory tract infection and S. pneumoniae colonization were 0,245.

Conclusion. Based on this research there is no significant corelation between exclusive breastfeeding and history of acute respiratory tract infections to Streptococcus pneumoniae colonization in nasopharynx of under 2 years old children.
\end{abstract} ISPA didapatkan dari hasil wawancara langsung pada saat pengambilan swab nasofaring anak. Analisis data menggunakan uji chi square.

Hasil. Hasil yang didapatkan pada penelitian ini sebanyak $63,3 \%$ dari anak usia bawah dua tahun ditemukan adanya kolonisasi S. Pneumoniae dari hasil swab nasofaring. Hasil analisis data menggunakan chi square diperoleh nilai $p=0,637$ untuk hubungan pemberian ASI eksklusif terhadap kolonisasi $S$. Pneumoniae, dan hubungan riwayat ISPA terhadap kolonisasi $S$. Pneumoniae nilai $\mathrm{p}=0,245$.

Kesimpulan. Tidak terdapat hubungan yang bermakna antara pemberian ASI eksklusif dan riwayat ISPA terhadap kolonisasi $S$. Pnuemoniae pada swab nasofaring anak usia bawah dua tahun. Kata kunci: ASI Ekslusif, ISPA, Kolonisasi, S. Pneumoniae

Background. Pneumonia is a main caused of mortality among children under five years old in the world. Streptococcus pneumoniae (S. pneumoniae) as a major cause of pneumonia is common bacteria in nasopharyngeal colonization. Exclusive breastfeeding and respiratory tract infection affect the $S$. pneumoniae colonization in nasopharynx, especially among 2 years old children, could be drive to pneumonia infection.

Objective. The aim of this research to determine the correlation between exclusive breastfeeding and history of acute respiratory tract infection with $S$. pneumoniae colonization among under 2 years old children.

Method. This research was a cross sectional study among 30 healthy children. We collected data about demographic indicator and risk factor of children has been taken by interview during nasopharyngeal swab colection. Streptococcus pneumoniae culture have been done related to core studies.
Keywords: Exclusive ASI, ISPA, Colonization, S. Pneumoniae

\section{Apa yang sudah diketahui tentang topik ini?}

- ASI memberikan protektif pada epitel nasofaring dengan mempengaruhi mikrobiota di nasofaring dan meningkatkan kadar IgA pada anak usia menyusui.

- Infeksi saluran pernafasan akut yang disebabkan oleh virus dapat mempengaruhi kolonisasi $S$. pneumoniae di nasofaring

\section{Apa yang ditambahkan pada studi ini?}

- Penelitian ini membahas tentang hubungan ASI eksklusif dan riwayat ISPA dalam 3 bulan terakhir terhadap kolonisasi S. pneumoniae pada swab nasofaring anak usia bawah dua tahun

\section{CORRESPONDING AUTHOR}

Name: Indri Permata Rani

Phone: +6282171503537

E-mail: ipermatarani@gmail.com

\section{ARTICLE INFORMATION}

Received: September $23^{r d}, 2020$

Revised: October $15^{\text {th }}, 2020$

Available online: October $31^{\text {st }}, 2020$ 


\section{Pendahuluan}

Pneumonia adalah infeksi pada jaringan intersitial paru yang menyebabkan terjadinya konsolidasi jaringan paru dan ganguan pertukaran gas. ${ }^{1}$ Menurut data World Heart Organization (WHO), pneumoia dan diare merupakan penyebab kematian terbanyak pada anak di dunia. ${ }^{2}$ Pada tahun 2019 sekitar 0.9 juta kematian tiap tahunnya pada anak usia bawah lima tahun disebabkan oleh pneumoia. ${ }^{3}$ Sementara itu, menurut data Kementrian Kesehatan Indonesia ditemukan sebanyak 4\% kasus pneumonia pada anak tahun 2018.4 Streptococcus pneumoniae merupakan bakteri gram positif yang dapat menyebabkan beberapa penyakit seperti pneumonia, meningitis, dan otitis media 5 .

Bakteri ini pada umumnya dapat membentuk kolonisasi di nasofaring anak yang bersifat asimptomatis dan menjadi sebuah penyakit apabila mencapai jaringan tubuh lain seperti paru, sawar darah di otak serta telinga tengah. ${ }^{6}$ Penelitian oleh Gili Regev-Yochay (2002) di ibu kota Israel sebanyak $43 \%$ anak usia 40 bulan ditemukan kolonisasi $S$. pneumoniae di nasofaring, sementara itu penelitian oleh Azilzal Rasini di Semarang (2010) sebanyak 43,2\% anak usia 6-60 ditemukan adanya kolonisasi $S$. pneumoniae di nasofaring.7,8

Berbeda halnya dengan penelitian di Cina oleh Chaoshan, 79,6\% anak ditemukan kolonisasi $S$. pneumoniae di nasofaring. ${ }^{9}$ Hal ini menunjukkan bahwa sekitar kurang lebih setengah dari anak sehat usia dibawah 5 tahun menjadi karier pneumonia yang berisiko terkena pneumonia pada suatu waktu.

Terbentuknya kolonisasi bakteri patogen di nasofaring merupakan hasil interaksi dari faktor host, agen dan lingkungan dalam satu waktu. Faktor host antara lain usia, ada tidaknya pemberian air susu ibu (ASI) secara eksklusif, imunisasi dan infeksi pada saluran nafas atas. Faktor lingkungan antara lain paparan asap rokok pasif, kepadatan hunian dan sosio-ekonomi10,11

Puncak dari kolonisasi S. pneumoniae sebanyak $55 \%$ pada usia 3 tahun. Sedangkan pada usia lebih dari 10 tahun rata-rata karier pneumoni stabil hanya sekitar 8\%. Kolonisasi pada nasofaring ini berawal di tahun pertama kehidupan yang meningkat sebelum usia 2 tahun, kemudian terus berkurang hingga usia remaja ${ }^{12}$.
Berdasarkan pada beberapa penelitian sebelumnya, pemberian ASI ekslusif dapat mempengaruhi mikrobiota di nasofaring dan meningkatkan kadar IgA pada anak usia menyusui. Kedua manfaat ini berperan dalam pertahanan tubuh terhadap adanya kolonisasi $S$. pneumoniae di nasofaring anak sehingga dapat menurunkan risiko kolonisasi $S$. pneumoniae di nasofaring. Penelitian Duffy et all memperlihatkan adanya penurunan dari jumlah kolonisasi S.pneumoniae pada usia 6 bulan ${ }^{13}$ pada bayi yang mendapat ASI eksklusif meskipun dari beberapa penelitian lain sebelumnya tidak ditemukan adanya hubungan terhadap kolonisasi $S$. pneumoniae di nasofaring anak ${ }^{14,15}$.

Hasil Riset Kesehatan Dasar (Riskesdas) Kementrian Kesehatan Indonesia di tahun 2018 prevalensi dari kejadian infeksi saluran pernafasan akut (ISPA) pada anak di Indonesia masih tinggi, yaitu sebanyak 4,4\% anak terkena ISPA dengan kelompok terbanyak dari usia 1-4 tahun. ${ }^{4}$ ISPA pada anak lebih banyak disebabkan oleh virus daripada bakteri, seperti rhinovirus, influenza virus, dan adenovirus. Beberapa penelitian yang ada sebelumnya menerangkan bahwa infeksi virus ini mempunyai reaksi terhadap epitel dari nasofaring serta mempengaruhi kolonisasi dari S. pneumoniae. ${ }^{6,17}$

Oleh karena itu, melalui penelitian ini penulis ingin mengetahui hubungan antara ASI ekslusif dan riwayat ISPA sebagai faktor risiko intrinsik dari anak terhadap kolonisasi $S$. pneumoniae yang terdapat di nasofaring.

\section{Metode}

Jenis penelitian ini adalah studi analitik dengan rancangan cross sectional, dengan variabel independennya adalah pemberian ASI eksklusif dan riwayat ISPA dalam 3 bulan terakhir dan variabel kolonisasi $S$. pneumoniae sebagai variabel dependen. Penelitian dilaksanakan pada AgustusDesember 2019. Populasi penelitian ini adalah anak usia bawah lima tahun yang datang ke puskesmas pada hari pengambilan swab nasofaring. Puskesmas yang menjadi tempat penelitian adalah Puskesmas Pegambiran, Puskesmas Pauh dan Puskesmas Andalas, sementara itu untuk kultur hasil swab nasofaring dilaksanakan di Laboratorium Mikrobiologi RSUP M Djamil dan Laboratorium Mikrobiology Eijckmen Institute Jakarta. 
Sampel penelitian yang dipilih adalah anak usia bawah dua tahun yang datang pada saat pengambilan sampel swab nasofaring yang memenuhi kriteria inklusi dan tidak memiliki kriteria eksklusi. Kriteria inklusi subjek: anak sehat usia bawah dua tahun yang bersedia diikutkan dalam penelitian setelah diberi informed consent kepada orang tua dan tidak sedang mengkonsumsi antibiotik. Kriteria eksklusi subjek: anak tidak kooperatif untuk diambel sampel.

Data penelitian terdiri dari data primer dan data sekunder. Data primer dari penelitian ini adalah kuisioner hasil wawancara penilaian faktor risiko host terhadap kolonisasi S. pneumoniae dan data sekunder adalah hasil kultur swab nasofaring pada anak tersebut.

Data dianalisis secara statistik berdasarkan variabel yang dinilai menggunakan sistem komputerisasi yaitu bivariat menggunakan uji chi square. Hubungan bermakna apabila didapatkan nilai $\mathrm{p}<0,05$.

\section{Hasil}

Penelitian ini dilakukan terhadap 30 anak usia bawah dua tahun dari 3 wilayah kerja Puskesmas berbeda, didapatkan 5 orang anak dari Puskesmas Pegambiran, 6 orang anak dari Puskesmas Pauh dan 19 anak dari Puskesmas Andalas.

\section{Gambaran Kolonisasi $S$. Pneumoniae pada Swab Nasofaring Anak Usia Bawah Dua Tahun di Kota Padang}

Tabel 1. Gambaran Kolonisasi S. Pneumoniae pada Swab Nasofaring Anak Usia Bawah Dua Tahun Menurut Kelompok Umur dan Jenis Kelamin

\begin{tabular}{|c|c|c|c|c|}
\hline \multirow{3}{*}{$\begin{array}{l}\text { Karakteristik } \\
\text { sampel }\end{array}$} & \multicolumn{4}{|c|}{$\begin{array}{c}\text { Kolonisasi } \text { S. Pneumoniae pada } \\
\text { Swab Nasofaring }\end{array}$} \\
\hline & \multicolumn{2}{|c|}{$(+)$} & \multicolumn{2}{|c|}{$(-)$} \\
\hline & $\mathbf{n}$ & $\%$ & $\mathbf{n}$ & $\%$ \\
\hline \multicolumn{5}{|l|}{ Jenis Kelamin } \\
\hline Perempuan & 8 & $61,5 \%$ & 5 & $38.5 \%$ \\
\hline Laki-laki & 11 & $64,7 \%$ & 6 & $35,3 \%$ \\
\hline \multicolumn{5}{|l|}{ Umur } \\
\hline$<6$ bulan & 3 & $60 \%$ & 2 & $40 \%$ \\
\hline 6-12 bulan & 3 & $100 \%$ & 0 & $0 \%$ \\
\hline 13-18 bulan & 6 & $60 \%$ & 4 & $40 \%$ \\
\hline$>18$ bulan & 7 & $58,3 \%$ & 5 & $41,7 \%$ \\
\hline Total & & $63,3 \%$ & & $36,7 \%$ \\
\hline
\end{tabular}

Hasil penelitian yang disajikan pada tabel 1 memperlihatkan bahwa sebanyak $63,3 \%$ anak usia bawah dua tahun ditemukan adanya kolonisasi S. Pneumoniae, berdasarkan jenis kelamin lebih banyak terdapat pada anak laki-laki $(64,7 \%)$ dibandingkan perempuan (61,5\%) sedangkan menurut kelompok umur anak kolonisasi S. pneumoniae banyak pada anak usia 6-12 bulan.

\section{Hubungan Riwayat ISPA terhadap} Kolonisasi S. Pneumoniae pada Swab Nasofaring Anak Usia Bawah Dua Tahun di Kota Padang

Tabel 2. Hubungan Riwayat Infeksi Saluran Pernafasan Atas dengan Kolonisasi S. Pneumoniae di Nasofaring Anak Usia Bawah Dua di Kota Padang

\begin{tabular}{|c|c|c|c|c|c|c|c|c|}
\hline \multirow{3}{*}{$\begin{array}{l}\text { Faktor } \\
\text { Risiko }\end{array}$} & \multicolumn{4}{|c|}{ Hasil Kultur } & \multirow{2}{*}{\multicolumn{2}{|c|}{ Total }} & \multirow{3}{*}{$\begin{array}{c}\text { OR } \\
95 \% \mathrm{CI}\end{array}$} & \multirow{3}{*}{$\begin{array}{c}\mathrm{p} \\
\text { Value }\end{array}$} \\
\hline & \multicolumn{2}{|r|}{+} & \multicolumn{2}{|r|}{ 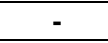 } & & & & \\
\hline & $\mathrm{n}$ & $\%$ & $\mathbf{n}$ & $\%$ & $\mathbf{n}$ & $\%$ & & \\
\hline \multicolumn{9}{|l|}{ iwayat } \\
\hline da & 17 & 68,0 & 8 & 32,0 & 251 & 100,0 & 3,1 & 0,245 \\
\hline idak Ada & 2 & 40,0 & 3 & 60,0 & 51 & 100,0 & $442-23,010$ & \\
\hline
\end{tabular}

Data yang terdapat pada tabel 5.4 dapat diiketahui bahwa 17 (68\%) dari anak yang mempunyai riwayat infeksi saluran pernapasan akut dalam 3 bulan terakhir terdapat kolonisasi $S$. pneumoniae dan 2 (40\%) dari anak yang tidak mempunyai riwayat infeksi saluran pernapasan akut ditemukan adanya kolonisasi $S$. pneumoniae di nasofaring. Nilai odds ratiio dari tabel 5.4 diatas memperlihatkan bahwa risiko anak yang mempunyai riwayat infeksi saliuran pernafasan akut dalam 3 bulan terakhir sebesar 3,18 kali dibandingkan anak yang tidak mempunyai riwayat ISPA dalam 3 bulan terakhir. Berdasarkan hasil uji statistik diperoleh nilai $p=0,245$ menunjukkan bahwa tidak terdapat hubungan yang bermakna antara riwayat ISPA dalam 3 bulan terakhir terhadap kolonisasi $S$. pneumoniae pada swab nasofaring anak usia bawah dua tahun di Kota Padang.

\section{Pembahasan}

Dari penelitian ini didapatkan prevalensi anak yang ditemukan kolonisasi $S$. pneumoniae adalah 63,3\%. Penelitian ini sesuai dengan penelitian yang dilakukan oleh C Murrad et al. pada tahun 2014-2015 di Bandung bahwa pada bayi usia 12 bulan sebanyak 68,4\% ditemukan kolonisasi $S$. pneumoniae di nasofaring dan penelitian Dunne et al. juga memperlihatkan prevalensi $S$. pneumoniae pada anak usia 12-24 bulan di Bandung pada 
tahun 2016 adalah 64\%.17,18 Berbeda dengan penelitian di beberapa negara maju, hanya sekitar $40-50 \%$ anak yang positif kolonisasi $S$. pneumoniae $^{19-20}$. Hal ini kemungkinan disebabkan karena di Indonesia masih belum umum penggunaan Pneumococcal Conjugate Vaksin (PCV) dibandingkan negara maju lainnya dan PCV ini sangat mempengaruhi terbentuknya kolonisasi $S$. pneumoniae. Dari hasil penelitian tingginya prevalensi kolonisasi $S$. pneumoniae ini disebabkan karena dari ketiga lokasi penelitian prevalensi pneumonia termasuk kelompok daerah yang banyak menderita pneumonia, ${ }^{21}$ dan faktor umur juga berpengaruh terhadap kolonisasi $S$. pneumoniae ini. berdasarkan hasil dari penelitian ini kelompok umur yang banyak ditemukan kolonisasi $S$. pneumoniae adalah usia 6-12 bulan, hal ini sesuai dengan penelitian yang dilakukan oleh Granat et al. pada anak usia bawah 1 tahun peningkatan kolonisasi $S$. pneumoniae dimulai saat usia 8 minggu kemudian meningkat drastis di usia 5 bulan yang dapat melebih $50 \%$ anak positif kolonisasi $S$. pneumoniae di nasofaring. ${ }^{22}$

Pada penelitian ini tidak terdapat hubungan bermakna antara pemberian ASI eksklusif dengan adanya kolonisasi $S$. pneumoniae pada nasofaring anak usia bawah dua tahun. Hal ini sesuai dengan penelitian oleh Maria G. Kouliiu et al dan Tefera. 23,24 Kandungan IgA dalam ASI dapat memberikan proteksi terhadap protein permukaan $H$. influenza sehingga pada penelitian Harabuchi ditunjukkan bahwa pemberian ASI eksklusif dapat berpengaruh terhadap kolonisasi $H$. influenza, ${ }^{25}$ tetapi hal ini tidak berlaku untuk $S$. pneumoniae karena pada protein permukaan $S$. pneumoniae terdapat Choline-binding protein $A$ Choline-binding protein $A$ yang dapat berikatan dengan polymeric Ig receptor sehingga bakteri ini bebas dari respon imun host melalui IgA. ${ }^{12,26}$

Riwayat ISPA dalam 3 bulan terakhir pada penelitian ini juga tidak terdapat hubungan yang bermakna terhadap kolonisasi $S$. pneumoniae $(\mathrm{p}=0,245)$ tetapi pada anak yang mempunyai riwayat ISPA 3,18 kali berisiko mempunyai kolonisasi S. pneumoniae. Sama halnya dengan penelitian yang dilakukan oleh Camelo-castilo et al. bahwa riwayat ISPA sebelum pengambilan swab nasofaring pada anak dapat mempengaruhi kolonisasi $H$. influenza dan Moraxela. Kolonisasi $H$, influenza ini dapat menekan S. pneumoniae karena terjadinya interaksi yang antagonis antar kedua bakteri ini. ${ }^{27}$ Hal lain yang menyebabkan tidak ada pengaruh riwayat ISPA terhadap kolonisasi $S$. pneumoniae karena pada saat pengambilan swab anak dalam keadaan sehat dan bebas dari tandatanda infeksi saluran pernafasan akut atas seperti flu, batuk dan demam. Penelitian yang dilakukan oleh Hendley et al. menunjukkan bahwa hasil dari swab nasofaring anak usia 1-9 tahun akan mengalami peningkatan kolonisasi saat anak mempunyai gejala infeksi saluran nafas seperti demam, flu, hidung tersumbat dan batuk sehingga terjadi peningkatan bakteri yang salah satu diantaranya adalah S. pneumonia. ${ }^{28}$ Begitu juga halnya dengan penelitian oleh Cappel et al. (2012) terhadap anak usia bawah lima tahun ditemukan adanya peningkatan kolonisasi bakteri $M$. Chataralis (22-36\%), H. Influenza (17-38\%), dan S. pneumoniae $12-32 \%$ pada anak yang ISPA akibat virus RSV. ${ }^{29}$

\section{Kesimpulan}

Berdasarkan hasil penelitian ini sebanyak 63,3\% anak usia bawah dua tahun di Kota Padang ditemukan adanya kolonisasi $S$. pneumoniae pada swab nasofaring dan tidak terdapat hubungan yang bermakna antara pemberian ASI eksklusif dan riwayat ISPA terhadap kolonisasi $S$. pneumoniae pada swab nasofaring anak. Diharapkan untuk penelitian selanjutnya menilai faktor risiko lain yang kemungkinan dapat mempengaruhi kolonisasi $S$. pneumoniae seperti imunisasi, riwayat pemakaian antibiotik, status gizi serta perlu penilaian interaksi mikroorganisme lain yang ada di nasofaring yang dapat mempengaruhi kolonisasi S. pneumoniae ini.

\section{Ucapan Terima Kasih}

Terima kasih kepada Dinas Kesehatan Kota Padang, Puskesmas Andalas, Puskesmas Pauh, Puskesmas Pegambiran atas izin melakukan penelitian di daerah kerja puskesmas tersebut, sehingga penelitian ini dapat berjalan lancar dan sesuai dengan yang direncanakan.

\section{Daftar Pustaka}

1. W. Sudoyo, Aru. Setiyohadi, Bambang. Alwi, Idrus. SK, Marcellius. Setiati, editor. Buku Ajar Ilmu Penyakit Dalam. Edisi V. Jakarta Pusat : Internal Publishing, 2009.

2. WHO (2013). Ending Preventable Child Deaths from Pneumonia and Diarrhoea. UNICEF. http://apps.who.int/iris/bitstream/10665/79200/1 /9789241505239_eng.pdf?ua=1-diakses Juni 2019 
3. Djojodiningrat D. Dispepsia fungsional. In: Setiati $\mathrm{S}$, Alwi I, Sudoyo AW, Simadibrata M, Setyohadi B, editors. Buku Ajar Ilmu Penyakit Dalam Jilid II. $6^{\text {th }}$ ed. Jakarta: Pusat Penerbitan Departemen Ilmu Penyakit dalam Fakultas Kedokteran Universitas Indonesia. 2014a. hlm. 1805-10.

4. Kementrian kesehatan RI. Hasil utama riskesdas 2018. 2018;61

5. O'Brien KL, Wolfson LJ, Watt JP, Henkle E, DeloriaKnoll M, McCall N, et al. Burden of disease caused by Streptococcus pneumoniae in children younger than 5 years: global estimates. Lancet [Internet]. 2009;374(9693):893-902. Tersedia pada: http://dx.doi.org/10.1016/S0140-6736(09)61204-6

6. Howard LM, Grijalva CG. The central role of pneumococcal colonization in the pathogenesis and control of pneumococcal diseases. Future Microbiol. 2018;13(13):1453-6.

7. Regev-yochay G, Dagan R, Raz M. Association Between Carriage of Streptococcus pneumoniae and Staphylococcus aureus in Children. JAMA. 2015;292(6):716-20.

8. Rasini azizal. Faktor risiko kolonisasi Streptococcus pneumonia pada nasofaring anak. 2010. (Fakultas Kedokteran Universitas Diponegoro)

9. Pan H, Cui B, Huang Y, Yang J, Ba-Thein W. Nasal carriage of common bacterial pathogens among healthy kindergarten children in Chaoshan region, southern China: A cross-sectional study. BMC Pediatr [Internet]. 2016;16(1):1-7. Tersedia pada: http://dx.doi.org/10.1186/s12887-016-0703-x

10. Mccool TL, Cate TR, Moy G, Weiser JN. The Immune Response to Pneumococcal Proteins during Experimental Human Carriage. J Exp Med. 2002;195(3).

11. Cardozo M, Nascimento-carvalho CM, Andrade SS, Silvany-neto $\mathrm{M}$, Daltro $\mathrm{CHC}$, Branda $\mathrm{S}$, et al. Prevalence and risk factors for nasopharyngeal carriage of Streptococcus pneumoniae among adolescents. J Med Microbiol. 2008;57:185-9

12. Bogaert D, De Groot R, Hermans PWM. Streptococcus pneumoniae colonization: The key to pneumococcal disease. Lancet Infect Dis. 2004;4(3):144-54

13. Duffy LC, Faden H, Wasielewski R, Wolf J, Krystofik D, Pediatrics TW. Exclusive Breastfeeding Protects Against Bacterial Colonization and Day Care Exposure to Otitis Media Linda. 2018;100(4)

14. Kaleida PH, Nativio DG, Chao H, Cowden SN. Prevalence of Bacterial Respiratory Pathogens in the Nasopharynx in Breast-Fed versus Formula-Fed Infants. Clin Microbiol J. 1993;31(10):2674-8

15. Bakhshaee M, Haghi MR, Naderi HR, Khomarian M, Ghazvini K. Breastfeeding, and nasopharyngeal colonization with common respiratory pathogens among children. Shiraz E Med J. 2015;16(8):1-4

16. Bartholomeusz A, Locarnini S. Respiratory Syncytial Virus, Adenoviruses, and Mixed Acute Lower Respiratory Infections in Children in a Developing Country Carlos. Antivir Ther. 2006;55(November 2005):52-5

17. Murad C, Dunne EM, Sudigdoadi S, Fadlyana E, Tarigan R, Pell CL, et al. Pneumococcal carriage, density, and co-colonization dynamics: A longitudinal study in Indonesian infants. Int J Infect Dis [Internet]. 2019;86:73-81. Tersedia pada: https://doi.org/10.1016/j.ijid.2019.06.024

18. Dunne EM, Murad C, Sudigdoadi S, Fadlyana E, Tarigan R, Indriyani SAK, et al. Carriage of streptococcus pneumonia, Haemophilus influenza, Moraxella catarrhalis, and staphylococcus aureus in Indonesian children: A cross-sectional study. PLoS One. 2018;13(4):1-12.

19. Navne JE, Børresen ML, Slotved HC, Andersson M. Nasopharyngeal bacterial carriage in young children in Greenland : a population at high risk of respiratory infections. EpidemiolInfect. 2016;144(May):3226-36.

20. Lee EK, Jun JK, Choi UY, Kwon HJ, Kim KH, Kang JH. Nasopharyngeal carriage rate and serotypes of Streptococcus pneumoniae and antimicrobial susceptibility in healthy Korean children younger than 5 years old: Focus on the influence of pneumococcal conjugate vaccination. Infect Chemother. 2013;45(1):76-84

21. Dinas Kesehatan Sumatera Barat. Profil Kesehatan Sumbar 2017. 2017;1-9. Tersedia pada: www.dinkes.sumbarprov.go.id

22. Granat SM, Mia Z, Ollgren J, Herva E, Das M, Piirainen $\mathrm{L}$, et al. Longitudinal study on the pneumococcal carriage during the first year of life in Bangladesh. Pediatr Infect Dis J. 2007;26(4):319-24.

23. Koliou $\mathrm{MG}$, et al. Risk factors for carriage of Streptococcus pneumoniae in children. BMC Pediatr [Internet]. 2018;18(1):144. Tersedia pada: http://www.biomedcentral.com/bmcpediatr/\%0Ahtt p://ovidsp.ovid.com/ovidweb.cgi?T=JS\&PAGE=refere nce \&D=emexb\&NEWS $=\mathrm{N} \& A N=621806812$

24. Tefera FB. Prevalence and Risk factor of Pneumococcal Colonization of The Nasopharinx amon Children Attending Kindergatten, Bahr dar, North West Ethiopia. Ababa University; 2015

25. Harabuchi Y, Faden H, Yamanaka N, Duffy L, Wolf J, Krystofik D. Human milk secretory IgA antibody to nontypeable Haemophilus influenzae: Possible protective effects against nasopharyngeal colonization. J Pediatr. 1994;124(2):193-8

26. Garcia-Rodriguez JA. Dynamics of nasopharyngeal colonization by potential respiratory pathogens. J Antimicrob Chemother. 2002;50(90003):59-74.

27. Camelo-Castillo A, Henares D, Brotons P, Galiana A, Rodríguez JC, Mira A, et al. Nasopharyngeal microbiota in children with invasive pneumococcal disease: Identification of bacteria with potential disease-promoting and protective effects. Front Microbiol. 2019;10

28. Hendley JO, Hayden FG, Winther B, Jo H, Fg H, Weekly WB. Weekly point prevalence of Streptococcus pneumoniae, Hemophilus influenzae, and Moraxella catarrhalis in the upper airways of normal young children: effect of respiratory illness and season. APMIS J. 2005;113(4):213-20

29. Marchisio P, Esposito S, Schito GC, Marchese A. Nasopharyngeal Carriage of Streptococcus pneumoniae in Healthy Children: Implications for the Use of Heptavalent Pneumococcal Conjugate Vaccine. Emerg Infect Dis J. 2002;8(5):479-84 